Article

\author{
ALMEIDA, J.F. ${ }^{1 *}$ \\ GARCÍA, G.P. ${ }^{2}$ \\ PÉREZ, R.A. ${ }^{1}$ \\ BRITO, J.D. ${ }^{1}$
}

\title{
Weeds Associated to Different Genotypes of CocoA IN THE ECUAdorian Amazon Region
}

\author{
Plantas Daninhas Associadas a Diferentes Genótipos se Cacau na Região \\ Amazônica Equatoriana
}

\begin{abstract}
This work was conducted in the Centro de Pesquisa, Pós-graduação e Preservação Amazônica (CIPCA), located in the Ecuadorian Amazon Region, with the goal to analyze the presence of weeds in promising clones of cocoa. The EET-95, EET-96 and EET-103 promising clones were evaluated, and the control sample was $\mathrm{CCN}-51$. To do so, the relative frequency and distribution of the existing weeds were determined, as well as their biomass, which was statistically analyzed by the ANOVA of a factor and the HSD Tukey's test. The presence of weeds was influenced by the studied genotypes, due to the fact that promising clones were associated to high frequency and distribution, such as Cyperus odoratus, Megathyrsus maximus, Sauvagesia erecta ssp. erecta. Other species appeared to be associated more to the CCN-51 clone, such as Scleria pterota, Paspalum conjugatuns and Rottboellia cochinchinensis. Higher weed biomass was verified in clone CCN-51.
\end{abstract}

Keywords: biomass, clones, distribution, frequency, Theobroma cacao.

RESUMO - O presente trabalho foi realizado no Centro de Pesquisa, Pós-graduação e Preservação Amazônica (CIPCA), localizado na Região Amazônica Equatoriana, com o objetivo de analisar a presença de plantas invasoras em clones promissores de cacau. Foram avaliados os clones promissores EET-95, EET-96 e EET-103 e se utilizou como controle o CCN-51. Para isso, foi determinada a frequência e a distribuição relativa de plantas daninhas presentes, assim como a biomassa destas, que foi analisada estatisticamente por meio da ANOVA de um fator e o teste HSD de Tukey. A presença de plantas daninhas foi influenciada pelos genótipos estudados, devido ao fato de que os clones promissores estavam associados com a alta frequência e a distribuição, como o Cyperus odoratus, Megathyrsus maximus, Sauvagesia erecta ssp. erecta. Outras espécies mostraram estar associadas em maior medida ao clone CCN-51, como Scleria pterota, Paspalum conjugatuns e Rottboellia cochinchinensis. A maior biomassa de plantas daninhas foi verificada no clone CCN-51.

Palavras-chave: biomassa, clones, distribuição, frequência, Theobroma cacao.

Copyright: This is an open-access article distributed under the terms of the Creative Commons Attribution License, which permits unrestricted use, distribution, and reproduction in any medium, provided that the original author and source are credited.

Received: January 21,2016

Approved: July 29, 2016

Planta Daninha 2018; v36:e018158823

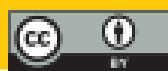

\section{INTRODUCTION}

In the Ecuadorian Amazon, cocoa is one of the main agricultural cultivations in the different production systems, given the quantity of areas and producers. There is the culture of producing domestic cocoa clones with fine aroma by producers who dedicate themselves to it. By the obtained yields and acquisition

1 Universidad Estatal Amazónica, Departamento de Ciencia de la Tierra. Puyo. Pastaza. Ecuador; ${ }^{2}$ Universidad de Ciego de Ávila, Facultad de Ciencias Agropecuarias, Ciego de Ávila. Cuba. 
ratio, this cultivation constitutes an important basis for the support of indigenous families. It is an economic alternative and contributes to the Plano do Bem Viver (Plan for Well-being) elaborated for this area, which helps the transformation of its production model.

The presence of weeds has a strong relation with the agro-ecosystem where they develop. Thus, many of them appear is some and not in others, according to the species of the plants existing in the place, as well as to factors such as physical, chemical and biological characteristics of the soil.

The interaction between weeds and biotic (genotype) and abiotic (climate conditions, cultivation system, control measures) environments was analyzed by Lotz et al. (1991), who pointed out that the mortality of weeds may be high, depending on the cultivated plants following them. In studies about weeds, Velasco Santos and Rico Hernández (2001) indicated that weed diversity was different in the evaluated agricultural cultivations; there was higher similarity of their floras in cultivations of beets and maize. In maize cultivation, 29 species of associated weed species were found, among which Digitaria sanguinalis and Cyperus rotundus predominated (Gámez et al., 2011).

The presented hypothesis was that the presence of weeds is influenced by cocoa genotypes, but this interaction was not studied with different fine aroma domestic clones from Ecuador; this is the reason why this work was conducted with the goal to analyze the presence of weeds in interaction with promising cocoa clones in the Ecuadorian Amazon region.

\section{MATERIALS AND METHODS}

The research was conducted between 2012 and 2015, in the Centro de Pesquisa, Pós-graduação e Preservação Amazônica (CIPCA), located in the Ecuadorian Amazon Region, in the Napo Province, in Cantón Arosemena Tola, via Puyo-Tena Km 44, close to the mouth of the rivers Piatúa and Anzu, at 527 a.s.1., on an Inceptisol soil type (Soil Survey Staff, 2003).

Cocoa (Theobroma cacao) specimens from clones EET-95, EET-96, EET-103 and CCN-51 were used; they were planted at a distance of $3.5 \times 3.5 \mathrm{~m}$ between them. The experimental project was with randomized blocks; they were part of the treatment for the indicated clones. Thirty plants per treatment were evaluated.

As a research criterion, a cocoa-banana-inga integrated system was established; these two last species were used as transitory shade. Some forest species also were part of the system as permanent shade.

In the statistical processing of data, the Statgraphics plus version 5.0 program was used. The adjustment to the normal data distribution for each treatment (Kolmogorov-Smirnov) and the variation homogeneity (Levene) were verified. The ANOVA of a factor and the HSD Tukey's test were performed. The maximum probability of a type I error was 0.05 .

\section{Characterization of weeds associated to the studied clones}

The frequency and distribution of weeds in the soil was determined according to Pérez et al. (2004), with a parameter of $1 \mathrm{~m}^{2}$. This parameter was placed 10 times per treatment in the soil area coinciding with the plant canopy.

The relative frequency (\%) was calculated according to the following formula:

$$
F_{r}=\frac{a}{A \cdot 100}
$$

$a=$ Number of times the species is found; $A=$ Total number of used samples.

The relative frequency (\%) was calculated according to the following formula:

$$
D_{r}=\frac{b}{B \cdot 100}
$$

$b=$ Number of species individuals; $B=$ Total of individuals from all the appeared species. 
The number of individuals per $\mathrm{m}^{-2}$ existing in each treatment was determined.

The biomass was determined as fresh mass from all existing weeds per clone. Ten samples were used in each treatment.

\section{RESULTS AND DISCUSSION}

\section{Characterization of weeds associated to the studied clones}

According to the relative frequency of weeds, Cyperus odoratus was the species presenting the highest frequency among all studied promising clones (100\%), followed by $M$. maximus (between 80 and 100\%), Achyranthes aspera (between 80 and 100\%), S. erecta ssp. erecta (between 60 and 100\%), Veronica officinalis (between 60 and 100\%), Digitaria decumbens (between 70 and 80\%), Leptochloa chloridiformis (between 10 and 90\%) and Urochloa decumbens (90\%) (Table 1).

In the analysis of the association between weeds and the studied clones, the highest frequency of the indicated species was found in clone EET-103, followed by EET-96 and EET-95. The lowest quantity of these species associated to clone CCN-51; however, other species that did not appear in the promising clones were associated to this one: Sida acuta, S. pterota, P. conjugatum and $R$. cochinchinensis.

As for the relative distribution, M. maximus. (51.4\% in clone EET-95), V. officinalis (28.47 in clone EET-103) and C. odoratus (14.4\% in clone EET-103) showed the highest values in the promising clones, whereas in $\mathrm{CCN}-51$, these species, even if present, showed lower values and a high distribution of $S$. acuta $(20.75 \%)$. These results indicated that these species are the prevailing ones in terms of total quantities determined in relation to the set of species around each clone (Table 2).

Table 1 - Weed relative frequency (Rf\%) based on the studied clones

\begin{tabular}{|c|c|c|c|c|c|}
\hline Weed & \multirow{2}{*}{ Family } & EET-95 & EET-96 & EET-103 & $\mathrm{CCN}-51$ \\
\hline Scientific name & & \multicolumn{4}{|c|}{$(\mathrm{Rf} \%)$} \\
\hline Achyranthes aspera L. & Amaranthaceae & 80 & 100 & 90 & 50 \\
\hline Arachis pintoi Krap. e Greg. & Fabaceae & 20 & 30 & 20 & 20 \\
\hline Baccharis lanceolata Kunth & Asteraceae & 10 & 0 & 10 & 0 \\
\hline Cyperus odoratus L. & Cyperaceae & 100 & 100 & 100 & 50 \\
\hline Cyperus rotundus $\mathrm{L}$. & Cyperaceae & 20 & 20 & 0 & 0 \\
\hline Corchorus orinocensis Kunth & Malvaceae & 0 & 10 & 0 & 0 \\
\hline Desmodium ovalifolium Prain & Fabaceae & 10 & 10 & 10 & 0 \\
\hline Digitaria decumbens Stent & Poaceae & 70 & 80 & 70 & 40 \\
\hline Dichondra repens (Forst e Forst) & Convolvulaceae & 0 & 30 & 30 & 10 \\
\hline Eclipta alba L. & Asteraceae & 20 & 30 & 40 & 10 \\
\hline Euphorbia chamaesyce L. & Euphorbiaceae & 0 & 20 & 0 & 0 \\
\hline Leptochloa chloridiformis Parodi & Poaceae & 10 & 0 & 90 & 0 \\
\hline $\begin{array}{l}\text { Megathyrsus maximus (Jacq.) B. K. Simon and } \\
\text { S.W. L. Jacobs }\end{array}$ & Poaceae & 100 & 80 & 100 & 20 \\
\hline Paspalum conjugatum Bergins & Poaceae & 0 & 0 & 0 & 50 \\
\hline Pothomorphe umbellata (L) Miq. & Piperaceae & 10 & 0 & 0 & 0 \\
\hline Rottboellia cochinchinensis (Lour) Clayton & Poaceae & 0 & 0 & 0 & 30 \\
\hline Sauvagesia erecta L. ssp. erecta & Ochnaceae & 60 & 90 & 100 & 50 \\
\hline Sida acuta L. Burmf & Malvaceae & 10 & 10 & 0 & 80 \\
\hline Scleria pterota Presl. & Cyperaceae & 0 & 0 & 0 & 50 \\
\hline Urochloa decumbens (Stapf) R. Webster. & Poaceae & 20 & 60 & 50 & 20 \\
\hline Veronica officinalis L. & Scrophulariaceae & 60 & 70 & 100 & 60 \\
\hline Xanthosoma undipes Koch & Araceae & 0 & 10 & 10 & 0 \\
\hline
\end{tabular}


Table 2 - Weed relative distribution (Rd\%) based on the studied clones

\begin{tabular}{|c|c|c|c|c|c|}
\hline Weed & \multirow{2}{*}{ Family } & EET-95 & EET-96 & EET-103 & $\mathrm{CCN}-51$ \\
\hline Scientific name & & \multicolumn{4}{|c|}{$(\mathrm{Rd} \%)$} \\
\hline Achyranthes aspera $\mathrm{L}$. & Amaranthaceae & 5.60 & 6.20 & 4.70 & 5.20 \\
\hline Arachis pintoi Krap. e Greg. & Fabaceae & 8.80 & 3.00 & 5.60 & 4.00 \\
\hline Baccharis lanceolata Kunth & Asteraceae & 0.06 & 0.00 & 0.05 & 0.00 \\
\hline Cyperus odoratus $\mathrm{L}$. & Cyperaceae & 9.40 & 10.70 & 14.40 & 8.00 \\
\hline Cyperus rotundus $\mathrm{L}$. & Cyperaceae & 0.10 & 0.50 & 0.46 & 0.00 \\
\hline Corchorus orinocensis Kunth & Malvaceae & 0.00 & 3.90 & 0.00 & 0.00 \\
\hline Desmodium ovalifolium Prain & Fabaceae & 0.06 & 0.06 & 0.06 & 0.00 \\
\hline Digitaria decumbens Stent & Poaceae & 4.20 & 6.00 & 3.00 & 1.90 \\
\hline Dichondra repens (Forst e Forst) & Convolvulaceae & 0.00 & 1.90 & 2.90 & 1.00 \\
\hline Eclipta alba L. & Asteraceae & 0.31 & 0.90 & 0.40 & 0.15 \\
\hline Euphorbia chamaesyce L. & Euphorbiaceae & 0.00 & 0.90 & 0.00 & 0.00 \\
\hline Leptochloa chloridiformis Parodi & Poaceae & 0.40 & 0.00 & 5.50 & 0.00 \\
\hline $\begin{array}{l}\text { Megathyrsus maximus (Jacq.) B. K. Simon and } \\
\text { S.W. L. Jacobs }\end{array}$ & Poaceae & 51.40 & 27.30 & 23.64 & 2.40 \\
\hline Paspalum conjugatum Bergins & Poaceae & 0.00 & 0.00 & 0.00 & 10.1 \\
\hline Pothomorphe umbellata (L) Miq. & Piperaceae & 0.06 & 0.00 & 0.00 & 0.00 \\
\hline Rottboellia cochinchinensis (Lour) Clayton & Poaceae & 0.00 & 0.00 & 0.00 & 18.0 \\
\hline Sauvagesia erecta L. ssp. Erecta & Ochnaceae & 3.00 & 6.20 & 6.80 & 5.50 \\
\hline Sida acuta L. Burmf & Malvaceae & 0.08 & 0.00 & 0.00 & 20.75 \\
\hline Scleria pterota Presl. & Cyperaceae & 0.00 & 0.00 & 0.00 & 9.90 \\
\hline Urochloa decumbens (Stapf) R. Webster. & Poaceae & 0.10 & 3.90 & 3.60 & 5.30 \\
\hline Veronica officinalis L. & Scrophulariaceae & 16.00 & 28.40 & 28.47 & 17.0 \\
\hline Xanthosoma undipes Koch & Araceae & 0.00 & 0.06 & 0.10 & 0.00 \\
\hline
\end{tabular}

When evaluating the number of individuals per $\mathrm{m}^{2}$, the species $M$. maximus, $V$. officinalis and $C$. odoratus were found as the ones with the greatest association with all clones; that is the reason why it is possible to indicate them as the prevailing ones in the area and independent from the established clones. Some species only appeared in clone CCN-51, such as S. pterota, $P$. conjugatum and $R$. cochinchinensis (Table 3).

Weed biomass in CCN-51 presented values of $1 \mathrm{~kg} \mathrm{~m}^{-2}$, which is significantly higher that what was obtained in the other clones; they oscillated between 0.5 and $0.7 \mathrm{~kg} \mathrm{~m}^{-2}$ (Figure 1).

As for the existing relation between the species and the appearance of weeds, Pérez et al. (2004) found results that show the presence of different weeds that are linked to the used species (Bean-Sunflower-Sweet potato-Corn), both in mono- and poly-cultures. The authors gave fundamental importance to the allelopathy phenomenon, produced in the case of sunflowers associated to beans. In this research, different types of weeds associated with the different studied clones and they showed differences regarding frequency, distribution and biomass, which correspond to the previously mentioned results.

Weeds qualitatively affected the production, since they reduced the quality of some species, due to the fact that they competed with cultivations for nutrients, water and light (Córdoba e Casas, 2003). In the present research, this criterion became evident in the promising clones, except for clone CCN-51, which, even if showing the highest biomass values, also presented the highest yield; that is the reason why this clone may develop with the weed levels used in this research. They correspond to the criteria by Altieri and Nichols (2007), regarding a agro-ecological management that permits the existence of weeds according to its interrelation with the cultivated species.

To conclude, it became evident that the presence of weeds was influenced by the studied genotypes, due to the fact that weeds were associated to promising clones with high frequency 
Table 3 - Number of weed individuals $\mathrm{m}^{-2}$ associated to the studied clones

\begin{tabular}{|c|c|c|c|c|c|}
\hline Weed & \multirow{2}{*}{ Family } & EET-95 & EET-96 & EET-103 & $\mathrm{CCN}-51$ \\
\hline Scientific name & & \multicolumn{4}{|c|}{$\left(\right.$ Ind $\left.\mathrm{m}^{-2}\right)$} \\
\hline Achyranthes aspera L. & Amaranthaceae & 8.9 & 10.3 & 8.1 & 10.6 \\
\hline Arachis pintoi Krap. e Greg. & Fabaceae & 14.1 & 5.0 & 9.7 & 8.1 \\
\hline Baccharis lanceolata Kunth & Asteraceae & 0.1 & 0 & 0.1 & 0 \\
\hline Cyperus odoratus L. & Cyperaceae & 15.1 & 17.7 & 24.7 & 16.3 \\
\hline Cyperus rotundus $\mathrm{L}$. & Cyperaceae & 0.2 & 0.8 & 0.8 & 0 \\
\hline Corchorus orinocensis Kunth & Malvaceae & 0 & 6.5 & 0 & 0 \\
\hline Desmodium ovalifolium Prain & Fabaceae & 0.1 & 0.1 & 0.1 & 0 \\
\hline Digitaria decumbens Stent & Poaceae & 6.8 & 10 & 5.2 & 4 \\
\hline Dichondra repens (Forst e Forst) & Convolvulaceae & 0 & 3.1 & 5.1 & 2.12 \\
\hline Eclipta alba $\mathrm{L}$. & Asteraceae & 0.6 & 1.6 & 0.8 & 0.32 \\
\hline Euphorbia chamaesyce L. & Euphorbiaceae & 0 & 1.6 & 0 & 0 \\
\hline Leptochloa chloridiformis Parodi & Poaceae & 0.7 & 0 & 9.5 & 0 \\
\hline $\begin{array}{l}\text { Megathyrsus maximus (Jacq.) B. K. Simon and } \\
\text { S.W. L. Jacobs }\end{array}$ & Poaceae & 82.2 & 45.3 & 40.6 & 10.2 \\
\hline Paspalum conjugatum Bergins & Poaceae & 0 & 0 & 0 & 20.6 \\
\hline Pothomorphe umbellata (L) Miq. & Piperaceae & 0.1 & 0 & 0 & 0 \\
\hline Rottboellia cochinchinensis (Lour) Clayton & Poaceae & 0 & 0 & 0 & 8.8 \\
\hline Sauvagesia erecta L. ssp. Erecta & Ochnaceae & 4.7 & 10.2 & 11.7 & 11.2 \\
\hline Sida acuta L. Burmf & Malvaceae & 0.08 & 0 & 0 & 20.75 \\
\hline Scleria pterota Presl. & Cyperaceae & 0 & 0 & 0 & 20.1 \\
\hline Urochloa decumbens (Stapf) R. Webster. & Poaceae & 0.2 & 6.5 & 6.2 & 10.8 \\
\hline Veronica officinalis L. & Scrophulariaceae & 25.9 & 47.1 & 48.9 & 30.5 \\
\hline Xanthosoma undipes Koch & Araceae & 0 & 0.1 & 0.2 & 0 \\
\hline
\end{tabular}

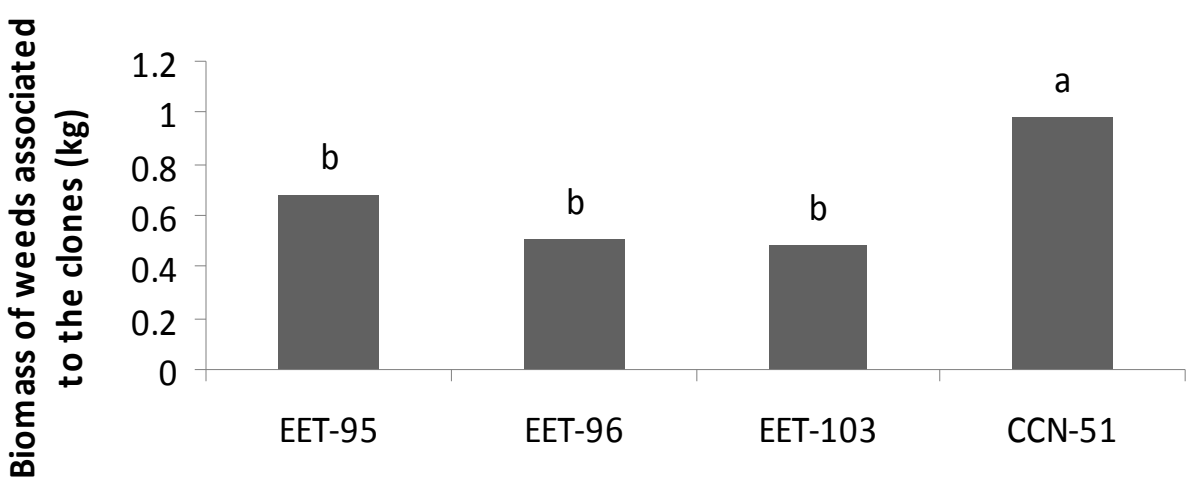

Clones

SIMPLE ANOVA. Tukey's test $\mathrm{p} \leq 0.05$. ES=0.06 $(\mathrm{n}=10)$. Different letters above the columns show statistical differences.

Figure 1 - Biomass of weeds associated to the studied clones.

and distribution, such as Cyperus odoratus, Megathyrsus maximus and to S. erecta ssp. erecta. Other species associated with CCN-51 to a greater extent, such as S. pterota, P. conjugatuns and $R$. cochinchinensis. The highest weed biomass was observed in clone CCN-51.

\section{REFERENCES}

Altieri M.A., Nicholls C. Conversión agroecológica de sistemas convencionales de producción: teoría, estrategias y evaluación. Ecosistemas. 2007;16:37-43.

Córdoba O., Casas H. Principales arvenses asociadas al cultivo del frijol en la Región Andina. Bogotá: Corpoica, 2003. 40p. (Boletín técnico, 20) 
Gámez L.A. et al. Caracterización de la flora arvense asociada a un cultivo de maíz bajo riego para producción de jojotos. Agron Trop. 2011;61:133-40.

Lotz L., Groenveld R.M., Habekott V.B. Reduction of growth and reproduction of Cyperus esculentus by specific crops. Weed Res. 1991;31:153-60.

Pérez G. et al. Evaluación de asociaciones de cultivo en rotación: frijol-girasol y boniato-maíz. Centro Agr. 2004;31:84-7.

Soil Survey Staff. Keys to soil taxonomy. 9th. ed. Washington: Natural Resourses Conservation Service/USDA, 2003. 332p.

Velasco Santos J.M., Rico Hernández E.R. Malas hierbas de cultivos de regadío del sureste de Castilla y León. Propuesta de un nuevo índice malherbológico [online]. Studia Bot. 2001;20:43-71. 